Article

\title{
Identification and In Silico Prediction of Anticoagulant Peptides from the Enzymatic Hydrolysates of Mytilus edulis Proteins
}

\author{
Meiling Qiao ${ }^{1}$, Maolin Tu ${ }^{2}$, Hui Chen ${ }^{1}$, Fengjiao Mao ${ }^{1}$, Cuiping $\mathrm{Yu}^{1}$ and Ming Du ${ }^{1, *}$ \\ 1 National Engineering Research Center of Seafood, School of Food Science and Technology, \\ Dalian Polytechnic University, Dalian 116034, China; qiaomeiling513@163.com (M.Q.); \\ realcrital@126.com (H.C.); fengjiaomao@163.com (F.M.); 18340854513@163.com (C.Y.) \\ 2 Department of Food Science and Engineering, Harbin Institute of Technology, Harbin 150090, China; \\ tumaolin012@163.com \\ * Correspondence: duming@dlpu.edu.cn; Tel.: +86-411-8633-2275; Fax: +86-411-8632-3262
}

Received: 18 April 2018; Accepted: 12 July 2018; Published: 19 July 2018

\begin{abstract}
Mytilus edulis is a typical marine bivalve mollusk. Many kinds of bioactive components with nutritional and pharmaceutical activities in Mytilus edulis were reported. In this study, eight different parts of Mytilus edulis tissues, i.e., the foot, byssus, pedal retractor muscle, mantle, gill, adductor muscle, viscera, and other parts, were separated and the proteins from these tissues were prepared. A total of 277 unique peptides from the hydrolysates of different proteins were identified by UPLC-Q-TOF-MS/MS, and the molecular weight distribution of the peptides in different tissues was investigated by sodium dodecyl sulfate-polyacrylamide gel electrophoresis (SDS-PAGE). The bioactivity of the peptides was predicted through the Peptide Ranker database and molecular docking. Moreover, the peptides from the adductor muscle were chosen to do the active validation of anticoagulant activity. The active mechanism of three peptides from the adductor muscle, VQQELEDAEERADSAEGSLQK, RMEADIAAMQSDLDDALNGQR, and AAFLLGVNSNDLLK, were analyzed by Discovery Studio 2017, which also explained the anticoagulant activity of the hydrolysates of proteins from adductor muscle. This study optimized a screening and identification method of bioactive peptides from enzymatic hydrolysates of different tissues in Mytilus edulis.
\end{abstract}

Keywords: Mytilus edulis; enzymatic hydrolysis; UPLC-Q-TOF-MS/MS; molecular docking; anticoagulant activity

\section{Introduction}

Bioactive peptides, as functional ingredients and pharmaceutical agents, have attracted much more attention in recent years [1-3]. With the development of new isolation and identification technologies, the study of the relationship of sequence and structure of bioactive peptides has rapidly evolved [3,4].

Mytilus edulis is a typical marine bivalve mollusk. Many kinds of nutritional and pharmaceutical benefits of Mytilus edulis have been reported, such as nourishing the liver and kidneys, adjusting blood pressure, curing night sweats, dizziness and impotence, and so on [5]. More and more bioactive peptides from the M. edulis whole body rather than different tissues, such as antimicrobial peptides [6,7], anti-inflammatory peptides [5], antioxidant peptides [8,9] and anticoagulant peptides, have been reported in recent years. Meanwhile, the bioactive peptides from different tissues of M. edulis are identifiable [10].

Thrombosis may cause serious complications such as an increase in portal venous pressure and an intestinal infarction. Previous surveys have indicated that the majority of serious diseases 
are thrombotic diseases, which may result in sudden death or long-term disability [11]. In recent years, bioactive peptides have received increasing attention. Similarly, there is an increasing need for anticoagulant and antithrombotic peptides to cure thrombosis. In these booming fields, those natural peptides with thrombin-inhibitory activity have attracted much more attention and have been evaluated extensively. Therefore, it is necessary to elaborate the preparation methods of target peptides. Indeed, blood clotting is a complicated physiological process controlled by a series of proteolytic reactions with comprehensive interactions $[12,13]$. The blood coagulation pathway involves the interaction of many plasma serine proteases known as blood clotting factors [5]. Therefore, the molecular mechanism of protein/peptide recognition has very important implications in the fields of biology, medicine, and pharmaceutical sciences [14]. Molecular docking technology has been widely used in this field in recent years [15-17].

The antithrombotic activity of M. edulis hydrolysate has been reported in several studies [6]. However, anticoagulant peptides were rarely isolated from M. edulis, and interactions between the peptide and thrombin have not been reported. The aim of this work was to prepare bioactive peptides from different tissues of $M$. edulis by trypsin digestion, and several possible anticoagulant peptides were evaluated by molecular docking and Peptide Ranker.

\section{Results and Discussion}

\subsection{Distribution of Proteins from Different Tissues}

The protein content of the different samples was shown in Figure 1. The adductor muscle, foot, pedal retractor muscle, byssus, gill, mantle, other parts, and viscera were sorted depending on the protein content. The protein content of the powder of S0 was $68 \%$. S1, S2, S3, S4, S6, S7, and S8 had significant differences compared with S0. S6 was significantly higher than S0. S2, S4, and S8 were significantly lower than $\mathrm{S} 0$. When the total tissue was considered to be $100 \%$, the dry weight of the different tissues will be $65.08 \pm 0.71,71.13 \pm 1.62,68.14 \pm 0.48,69.92 \pm 1,59.25 \pm 0.83,63.41 \pm 0.23$, $79.22 \pm 0,51.84 \pm 0.25,58.73 \pm 0.72$ percent, respectively.

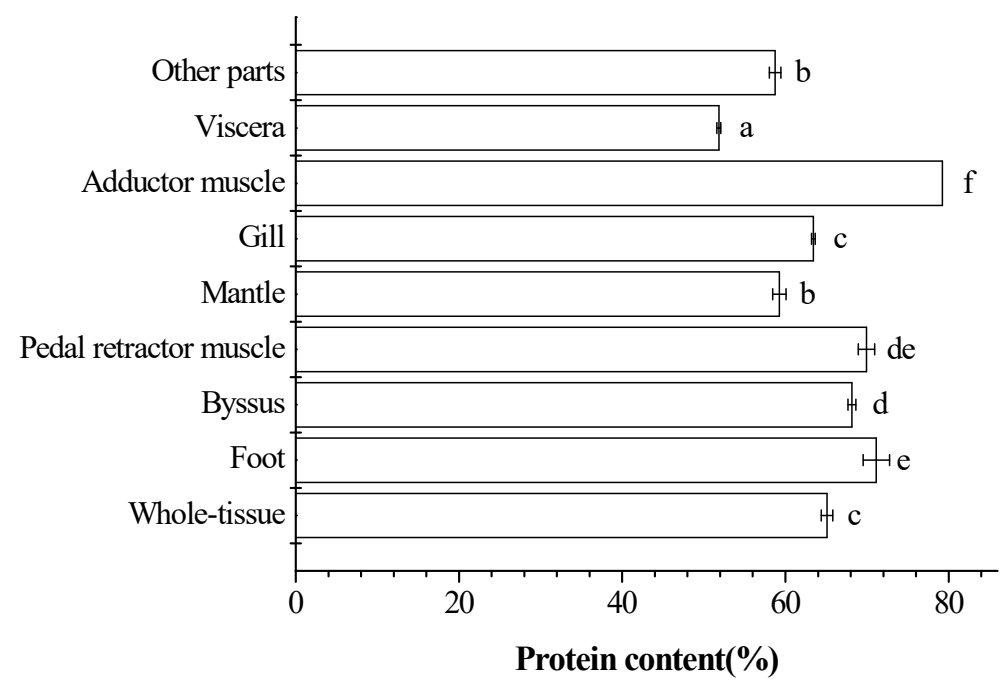

Figure 1. Eight different parts of Mytilus edulis tissues, i.e., foot, byssus, pedal retractor muscle, mantle, gill, adductor muscle, viscera, and other parts, from Mytilus edulis were separated and prepared. The protein content of different tissues was measured by the Kjeldahl method. Values are mean \pm SD $(n=3-6)$. Different letters beside the bars represent a significant difference between the values.

As shown in Figure 2, the proteins of byssus, viscera, and others about $40 \mathrm{kDa}$ proteins were more noticeable than other samples. Dissolved protein concentrations were $7.45 \pm 0.11,4.53 \pm 0.21$, 
$2.88 \pm 0.28,5.71 \pm 0.05,5.47 \pm 0.08,5.83 \pm 0.09,5.57 \pm 0.07,4.05 \pm 0.18$ and $5.57 \pm 0.06 \mathrm{mg} / \mathrm{mL}$, respectively, as determined by the BCA method $\left(R^{2} \geq 0.998\right)$. It was noteworthy that the protein concentration of byssus was too low to affect later enzymatic hydrolysis. As shown in Figure 2A,B, there was different protein distribution, i.e., the protein band of $100 \mathrm{kDa}$ in $25^{\circ} \mathrm{C}$ water ( $\left.\mathrm{pH} 7.0\right)$ was not soluble in $45^{\circ} \mathrm{C}$ water ( $\mathrm{pH} 8.5$ ), which probably contributed to the different peptide identification. The effect of enzymatic hydrolysis and the properties of peptides were affected by the solubility of proteins. SDS-PAGE of the enzymatic hydrolysates is shown in Figure 2C, which indicates that the hydrolysis degree of S3 and S6 is much higher than in the other samples.

(A)

KDa M S0 S1 S2 S3 S4 S5 S6 S7 S8

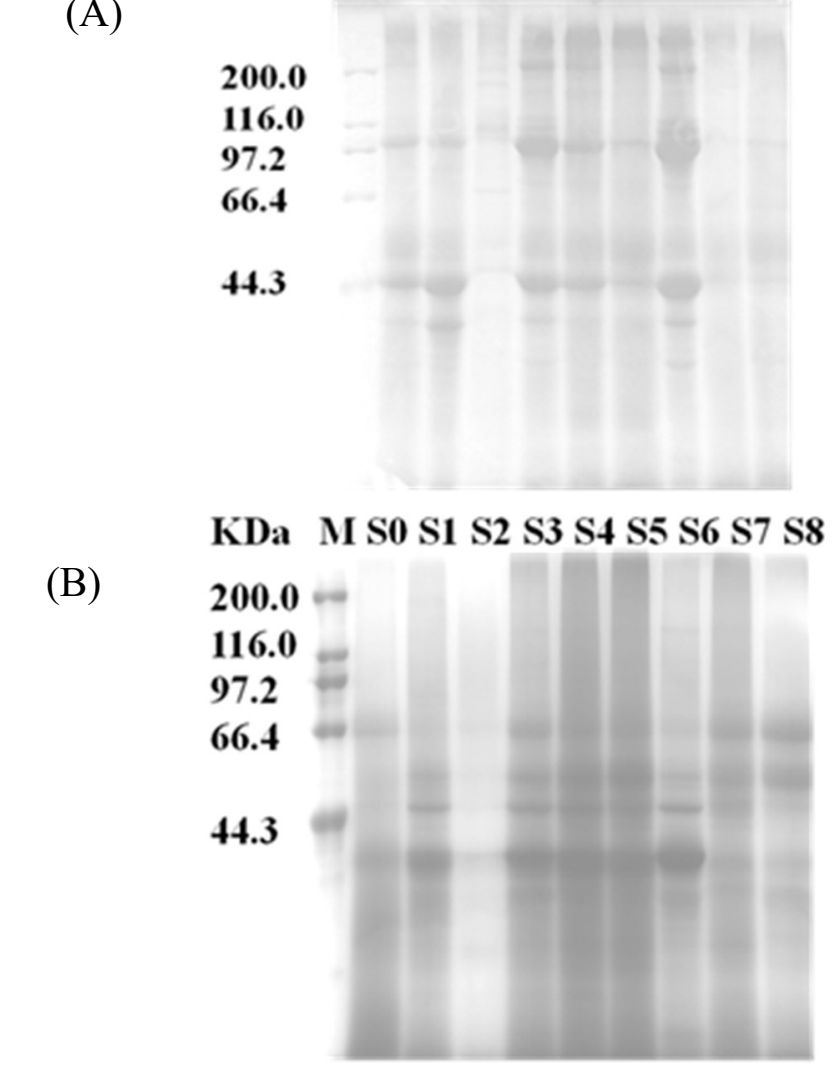

(C)

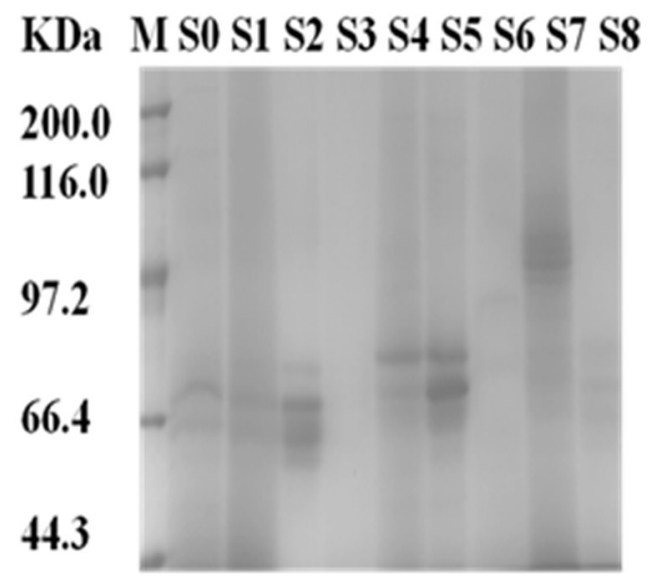

Figure 2. (A) Soluble proteins in $45^{\circ} \mathrm{C}$ water at $\mathrm{pH} 8.5$; (B) soluble proteins in $25^{\circ} \mathrm{C}$ water at $\mathrm{pH} 7.0$ (C) proteins and peptides in the enzymatic hydrolysates. S0-Whole tissue; S1-Foot; S2-Byssus; S3-Pedal retractor muscle; S4-Mantle; S5-Gill; S6-Adductor muscle; S7-Viscera; S8-Other parts. 


\subsection{Identification of the Peptides in Hydrolysates}

A total of 277 peptides were identified from M. edulis by UPLC-Q-TOF-MS; 109, 14, 116, 67, 37, 144,19 , and 36 peptides were identified from S1 to S8, respectively. However, 47 peptides were derived from the hydrolysate of S0. The number of peptides from S1, S3, S4, and S6 was significantly higher than for S0. Over 70\% of the peptides from S0 were also identified in all the other tissues separately. All these results indicated that more peptides would be identified if the samples were pretreated by separating the different tissues from $M$. edulis rather than that of the whole part. The number of peptides identified from $\mathrm{S} 6$ was the highest among all the samples, and the studies on the adductor muscle were also more extensive in recent years [18-20], which indicated that the adductor muscle from M. edulis could be a potential source of anticoagulant peptides.

\subsection{Activity Prediction and Molecular Docking of Peptides}

There were 25 peptides that showed higher scores $(>50)$, listed in Table 1 . The number of peptides derived from S0 to S8 was 5, 9, 6, 11, 7, 6, 12, 5, and 5, respectively. The results showed that the adductor muscle may contain more bioactive peptides.

Table 1. Peptides released from Mytilus edulis proteins hydrolyzed by trypsin.

\begin{tabular}{|c|c|c|c|c|}
\hline Sequence & $\begin{array}{l}\text { Length of } \\
\text { Peptide }\end{array}$ & $\begin{array}{l}\text { Molecular } \\
\text { Weight }\end{array}$ & Tissues & $\begin{array}{l}\text { Peptide } \\
\text { Ranker }\end{array}$ \\
\hline GPAGIIGLIGPK & 12 & 857.4555 & $\mathrm{~S} 1, \mathrm{~S} 2, \mathrm{~S} 3$ & 0.83 \\
\hline GPIGPAGGKGPTGPK & 15 & 1289.7138 & S2 & 0.83 \\
\hline NDFDKDFFK & 9 & 1174.5336 & S6 & 0.78 \\
\hline AGLQFPVGR & 9 & 569.3174 & S0, S3, S4, S5, S6, S7, S8 & 0.76 \\
\hline GYSAELFR & 8 & 792.3822 & $\mathrm{~S} 1$ & 0.71 \\
\hline SPNFTKPGK & 9 & 801.4345 & S1 & 0.7 \\
\hline GPTGPQGLR & 9 & 881.4739 & $\mathrm{~S} 1, \mathrm{~S} 2$ & 0.68 \\
\hline FPGQLNADLR & 10 & 1129.5894 & S3, S5 & 0.67 \\
\hline LAVNMVPFPR & 10 & 1029.5439 & S0, S3, S4, S5, S6, S7, S8 & 0.67 \\
\hline SYSAELFR & 8 & 971.4715 & $\mathrm{~S} 3, \mathrm{~S} 4, \mathrm{~S} 6$ & 0.65 \\
\hline TATSPFFK & 8 & 897.4602 & $\mathrm{~S} 3, \mathrm{~S} 4, \mathrm{~S} 7, \mathrm{~S} 8$ & 0.65 \\
\hline KLAVNMVPFPR & 11 & 1270.7253 & S0 & 0.64 \\
\hline AVFPSIVGRPR & 11 & 1197.7004 & S0, S1, S2, S3, S4, S5, S6, S7, S8 & 0.62 \\
\hline LSHYAFSSLR & 10 & 1180.4689 & S5 & 0.62 \\
\hline AAFLLGVNSNDLLK & 14 & 1473.8192 & S3, S6 & 0.59 \\
\hline GIQGPEGELGPVGK & 14 & 1337.7210 & S2 & 0.58 \\
\hline TLYGFGG & 7 & 713.3405 & S5 & 0.58 \\
\hline WSYAPQSR & 8 & 993.4698 & $\mathrm{~S} 1, \mathrm{~S} 3, \mathrm{~S} 4, \mathrm{~S} 6$ & 0.58 \\
\hline VQQELEDAEERADSAEGSLQK & 21 & 2331.0806 & S6 & 0.57 \\
\hline AGFAGDDAPR & 10 & 975.4435 & $\mathrm{~S} 1, \mathrm{~S} 2, \mathrm{~S} 3, \mathrm{~S} 4, \mathrm{~S} 6, \mathrm{~S} 7, \mathrm{~S} 8$ & 0.56 \\
\hline SFVNDIFER & 9 & 824.5024 & S0 & 0.56 \\
\hline NLNADVDSVRESLEEEQESKSDLQR & 25 & 2889.364 & S1 & 0.55 \\
\hline SPNFGRPGNASK & 12 & 1230.6178 & S3, S6 & 0.55 \\
\hline ALAADINLR & 9 & 956.5409 & S6 & 0.53 \\
\hline RMEADIAAMQSDLDDALNGQR & 21 & 2319.064 & S1, S6 & 0.5 \\
\hline
\end{tabular}

Note: S0—Whole tissue; S1—Foot; S2—Byssus; S3—Pedal retractor muscle; S4—Mantle; S5—Gill; S6—Adductor muscle; S7-Viscera; S8-Other parts. Peptides with a score greater than 0.5 were considered to be positive results in the present study.

The CDCOCKER docking simulation was used to elucidate the molecular mechanisms of interactions between human thrombin and peptides from M. edulis. Every peptide has 10 molecular antagonists as docking poses for the docking simulation, as shown in Figure 3A. A peptide named TYS (containing hirudin fragment 54-62) was combined with thrombin and played an important role in inhibiting thrombin. The peptides derived from M. edulis proteins may show inhibitory activity against thrombin with a similar mechanism if the peptide and hirudin showed a similar interaction domain with thrombin (TYS). The yellow sphere was defined as the active site and binding site of peptides in Figure 3B. The score of TYS was 170.13. The number of peptides with a higher score $(>170)$ derived 
from S0 to S8 was 7, 45, 33, 34, 16, 3, 55, 1, and 3 (Table 2), respectively. The percentage of peptides from the adductor muscle was much higher, so the antithrombotic activity of $\mathrm{S} 6$ was determined in the following study.

Table 2. Molecular docking of predicted antithrombotic peptides.

\begin{tabular}{|c|c|c|c|}
\hline Peptide & Length of Peptide & Tissue(s) & -CDOCKERENERGY \\
\hline LTQENFDLQHQVQELDGANAGLAK & 24 & S1 & 311.73 \\
\hline VQQELEDAEERADSAEGSLQK & 21 & S6 & 303.38 \\
\hline TLADLQKEEDKVNHLNK & 17 & S1 & 282.78 \\
\hline MEKENALDRAEQLEQK & 16 & S1 & 272.87 \\
\hline KKLEQDINELEMALDTSNR & 19 & S1 & 270.74 \\
\hline SIQTENDLDNTQTQLQDVQAK & 21 & S6 & 264.94 \\
\hline AKLESTLDEMEDNLER & 16 & S1 & 255.701 \\
\hline ITIQQELEDARSLLEHAER & 19 & $\mathrm{~S} 1, \mathrm{~S} 2, \mathrm{~S} 3, \mathrm{~S} 6$ & 254.26 \\
\hline LADELRQEQDNYKNAESLR & 19 & S6 & 251.11 \\
\hline KLEQDINELEMALDTSNR & 18 & S1 & 249.98 \\
\hline HQEALNDLTDQLEHMGK & 17 & $\mathrm{~S} 1, \mathrm{~S} 2, \mathrm{~S} 3, \mathrm{~S} 4, \mathrm{~S} 6$ & 241.79 \\
\hline RRHQEALNDLTDQLEHMGK & 20 & $\mathrm{~S} 1, \mathrm{~S} 6$ & 238.67 \\
\hline NRLQGELDDLLIEVER & 16 & S1 & 237.02 \\
\hline VKELQTEIDTAHTEAR & 16 & S1 & 236.54 \\
\hline DLEETTLQHEAQVSSLR & 17 & S6 & 236.102 \\
\hline MIEEAEDVASITMNKYR & 17 & $\mathrm{~S} 1, \mathrm{~S} 6$ & 235.72 \\
\hline RHQEALNDLTDQLEHMGK & 18 & $\mathrm{~S} 1, \mathrm{~S} 2, \mathrm{~S} 3, \mathrm{~S} 4 \mathrm{~S} 6$ & 232.22 \\
\hline WIAEEADKKYEEAAR & 15 & S1, S2, S3, S6 & 231.80 \\
\hline AAVLEYLAAEVLELAGNAAR & 20 & S0 & 231.28 \\
\hline LLDEEDAASELEGLKK & 16 & S1 & 230.16 \\
\hline NQLIIEIDSLQAMNDGLQK & 19 & $\mathrm{~S} 2, \mathrm{~S} 3, \mathrm{~S} 6$ & 228.63 \\
\hline LADELRQEQDNYK & 13 & $\mathrm{~S} 2, \mathrm{~S} 3, \mathrm{~S} 6$ & 227.66 \\
\hline QNLQVQLAAIQSDYDNLNAR & 20 & S6 & 227.36 \\
\hline VIDLEEQLTVVGANIK & 16 & S1, S6 & 226.86 \\
\hline NLAEEIHELTEQLSEGGR & 18 & S6 & 226.02 \\
\hline AAEERADRLQAEVNR & 15 & $\mathrm{~S} 2, \mathrm{~S} 3, \mathrm{~S} 6$ & 225.98 \\
\hline IRELEDSLDSEREMR & 15 & S1, S4 & 225.89 \\
\hline IRDLENELEADQRR & 14 & $\mathrm{~S} 2, \mathrm{~S} 3, \mathrm{~S} 4, \mathrm{~S} 6$ & 225.40 \\
\hline MIEEAEDVASITMNK & 15 & S6 & 223.61 \\
\hline ELEDSLDSEREMR & 13 & $\mathrm{~S} 2, \mathrm{~S} 3, \mathrm{~S} 6$ & 222.18 \\
\hline RMEADIAAMQSDLDDALNGQR & 21 & S1, S6 & 220.49 \\
\hline ENALDRAEQLEQK & 13 & $\mathrm{~S} 1, \mathrm{~S} 6$ & 220.44 \\
\hline EVDRLEDELLTEK & 13 & S6 & 219.35 \\
\hline EITVRLEEAEAFAQR & 15 & S6 & 217.95 \\
\hline TFDREGQGYISGAEMR & 16 & S1 & 217.67 \\
\hline KLAITEVDLERAEAR & 15 & S1 & 214.16 \\
\hline ATQEVVEELEGVKR & 14 & $\mathrm{~S} 1, \mathrm{~S} 2, \mathrm{~S} 3$ & 213.487 \\
\hline LTEVQLQVTALTNDKR & 16 & $\mathrm{~S} 2, \mathrm{~S} 3, \mathrm{~S} 6$ & 213.42 \\
\hline LQGELDDLLIEVER & 14 & S1 & 213.06 \\
\hline AVFVDLEPTVVDEVR & 15 & S5 & 212.988 \\
\hline VQFNLKDYQSSANVKHAVDK & 20 & $\mathrm{~S} 4$ & 212.98 \\
\hline IRDLENELEADQR & 13 & $\mathrm{~S} 1, \mathrm{~S} 2, \mathrm{~S} 3, \mathrm{~S} 4, \mathrm{~S} 6$ & 212.26 \\
\hline HQGVMVGMGQKDSYVGDEAQSKR & 23 & $\mathrm{~S} 1$ & 212.01 \\
\hline ELQTEIDTAHTEAR & 14 & S1 & 211.61 \\
\hline LEDAMGTSTTVSEVSR & 16 & S6 & 211.59 \\
\hline TLQGEMAQQDEQISK & 15 & S1 & 211.51 \\
\hline IAIIITDGKPTDINATQR & 18 & $\mathrm{~S} 2, \mathrm{~S} 3, \mathrm{~S} 4$ & 211.34 \\
\hline SGVLVRPK & 8 & S0, S8 & 210.81 \\
\hline MSADSKIDALEGSNSR & 16 & $\mathrm{~S} 1, \mathrm{~S} 2, \mathrm{~S} 3, \mathrm{~S} 6$ & 209.52 \\
\hline DLENELEADQRR & 12 & $\mathrm{~S} 2, \mathrm{~S} 3, \mathrm{~S} 6$ & 209.289 \\
\hline AQYEETSDTIEALRR & 15 & S1 & 209.038 \\
\hline DLYANTVLSGGTTMFPGIADR & 21 & S6 & 207.485 \\
\hline QLDDTRNQLSVSER & 14 & S6 & 206.48 \\
\hline LTGELEDLGIDVER & 14 & S6 & 206.25 \\
\hline QIAEHEQEIQSLTR & 14 & S6 & 205.14 \\
\hline ELDDVQSQLSHSMK & 14 & S1 & 204.91 \\
\hline QLEDAEHTIGSLTK & 14 & S1 & 204.72 \\
\hline ELEGELDSEQRR & 12 & S6 & 203.33 \\
\hline LAEAEQAAEAANAK & 14 & S1 & 202.27 \\
\hline
\end{tabular}


Table 2. Cont.

\begin{tabular}{|c|c|c|c|}
\hline Peptide & Length of Peptide & Tissue(s) & -CDOCKERENERGY \\
\hline IRELEDSLDSER & 12 & $\mathrm{~S} 2, \mathrm{~S} 3, \mathrm{~S} 4$ & 202.17 \\
\hline ALDSMQASLEAEAK & 14 & S2, S3, S6 & 202.096 \\
\hline QVAELTSITDQLTMK & 15 & S6 & 201.63 \\
\hline INELAAQVSSAQAQKR & 16 & S1 & 201.27 \\
\hline DKSALTSQLEEAKR & 14 & $\mathrm{~S} 1$ & 201.151 \\
\hline KNAENELGEVTVR & 13 & $\mathrm{~S} 0, \mathrm{~S} 2, \mathrm{~S} 3, \mathrm{~S} 4, \mathrm{~S} 6$ & 200.88 \\
\hline LLSGVTIAQGGVLPNIQAVLLPK & 23 & So & 200.55 \\
\hline AKIEDDYNSLQK & 12 & S1, S6 & 198.5 \\
\hline SYYDTSREENDIRR & 14 & $\mathrm{~S} 6$ & 197.19 \\
\hline SYELPDGQVITIGNER & 16 & S0,S1, S2, S3, S4, S6, S7, S8 & 196.76 \\
\hline VTDLQSELENAQK & 13 & $\mathrm{~S} 2, \mathrm{~S} 3, \mathrm{~S} 6$ & 196.65 \\
\hline DLENELEADQR & 11 & S6 & 196.13 \\
\hline LDLAGRDLTDYLMK & 14 & $\mathrm{~S} 1, \mathrm{~S} 2, \mathrm{~S} 3, \mathrm{~S} 4, \mathrm{~S} 6$ & 191.19 \\
\hline KVGINYQPPTVVPGGDLAK & 19 & SO & 190.22 \\
\hline DIEDLETTLAK & 11 & S1 & 189.759 \\
\hline SALYEDTFIPEVIRPR & 16 & $\mathrm{~S} 2, \mathrm{~S} 3, \mathrm{~S} 6$ & 188.36 \\
\hline LEDDQSLIAQLQR & 13 & S6 & 188.31 \\
\hline YEEESENASSLR & 12 & $\mathrm{~S} 2, \mathrm{~S} 3, \mathrm{~S} 4, \mathrm{~S} 6$ & 188.24 \\
\hline MSATFIGNSTAIQELFKR & 18 & S5 & 184.40 \\
\hline NAENELGEVTVR & 12 & S6 & 183.23 \\
\hline AMSIMNSFVNDIFER & 15 & S0, S2, S3, S4, S5, S8 & 178.809 \\
\hline DSYVGDEAQSKR & 12 & $\mathrm{~S} 1, \mathrm{~S} 2, \mathrm{~S} 3, \mathrm{~S} 4$ & 177.848 \\
\hline SALTSQLEEAKR & 12 & S1 & 177.63 \\
\hline DSYVGDEAQSK & 11 & S1, S2, S3 & 177.572 \\
\hline KRITIQQELEDAR & 13 & $\mathrm{~S} 2, \mathrm{~S} 3, \mathrm{~S} 6$ & 177.35 \\
\hline KAQSLIDEAEQR & 12 & $\mathrm{~S} 2, \mathrm{~S} 3, \mathrm{~S} 4$ & 177.22 \\
\hline AQSLIDEAEQR & 11 & S4 & 176.453 \\
\hline ETVQASDEDRR & 11 & S6 & 176.32 \\
\hline QLENENAALQK & 11 & $\mathrm{~S} 2, \mathrm{~S} 3$ & 175.83 \\
\hline KMEGENSEMKR & 11 & S1 & 174.67 \\
\hline QEYDESGPSIVHR & 13 & S6 & 174.00 \\
\hline LTDEQVDDIIR & 11 & S6 & 173.52 \\
\hline ATQEAVEDLER & 11 & S2, S3 & 173.43 \\
\hline KLAITEVDLER & 11 & S6 & 173.15 \\
\hline SKLQSEVTEINR & 12 & S1 & 172.71 \\
\hline ELEDSLDSER & 12 & S3, S6 & 172.60 \\
\hline ITIQQELEDAR & 11 & S2, S3, S6 & 171.94 \\
\hline LTDMIDKLQSK & 11 & S1 & 171.79 \\
\hline AAFLLGVNSNDLLK & 14 & $\mathrm{~S} 2, \mathrm{~S} 3, \mathrm{~S} 6$ & 171.476 \\
\hline SLENTIAELQHK & 12 & S2, S3, S6 & 170.94 \\
\hline ENKNLADEIR & 12 & S1 & 170.32 \\
\hline
\end{tabular}

Note: S0—Whole tissue; S1-Foot; S2—Byssus; S3—Pedal retractor muscle; S4—Mantle; S5—Gill; S6—Adductor muscle; S7-Viscera; S8-Other parts. Peptides with scores greater than 170 were considered to be anticoagulant peptides in the present study.

Three peptides, VQQELEDAEERADSAEGSLQK (P1), RMEADIAAMQSDLDDALNGQR (P2), and AAFLLGVNSNDLLK (P3), might be more active due to the higher evaluation levels of activity by both Peptide Ranker and molecular docking. The interaction of antithrombotic peptides with thrombin was shown in Figure 3C. Amino acids combined from the thrombin of P1, P2, and P3 were Lys36-Gln38-Thr74-Arg75-Tyr76-Ile82-Met84, Gln38-Arg67-Thr74-Arg75-Tyr76-Ile82-Met84, and Lys36-Arg67-Thr74, respectively. As is well known, Phe34-Leu65-Arg73-Thr74-Arg75-Tyr76-Glu80Lys81-Ile82 is the active site 2 in the thrombin molecule [21], and Lys36-Arg73-Arg77-Lys149E in the thrombin molecule works as the binding motif to recognize fibrinogen [22]. The number of combined amino acids from P1-P3 was 5, 4, and 2; their scores were 303.38, 220.49, and 171.47. These results indicated that the more essential amino acids were combined, the higher the score and the stronger the activity [23]. The score of LTQENFDLQHQVQELDGANAGLAK was the highest. However, there were only 5 interactive amino acids involved in the active center of thrombin include, Gln38-Arg73-Thr74-Tyr76-Ile82, which was less than that of P1. Moreover, P1 was derived from the adductor muscle, P2 was derived from the foot and adductor muscle, and P3 was derived from 
the byssus, pedal retractor muscle, and adductor muscle. Therefore, the adductor muscle may be a potential source for producing peptides with anticoagulant activity.
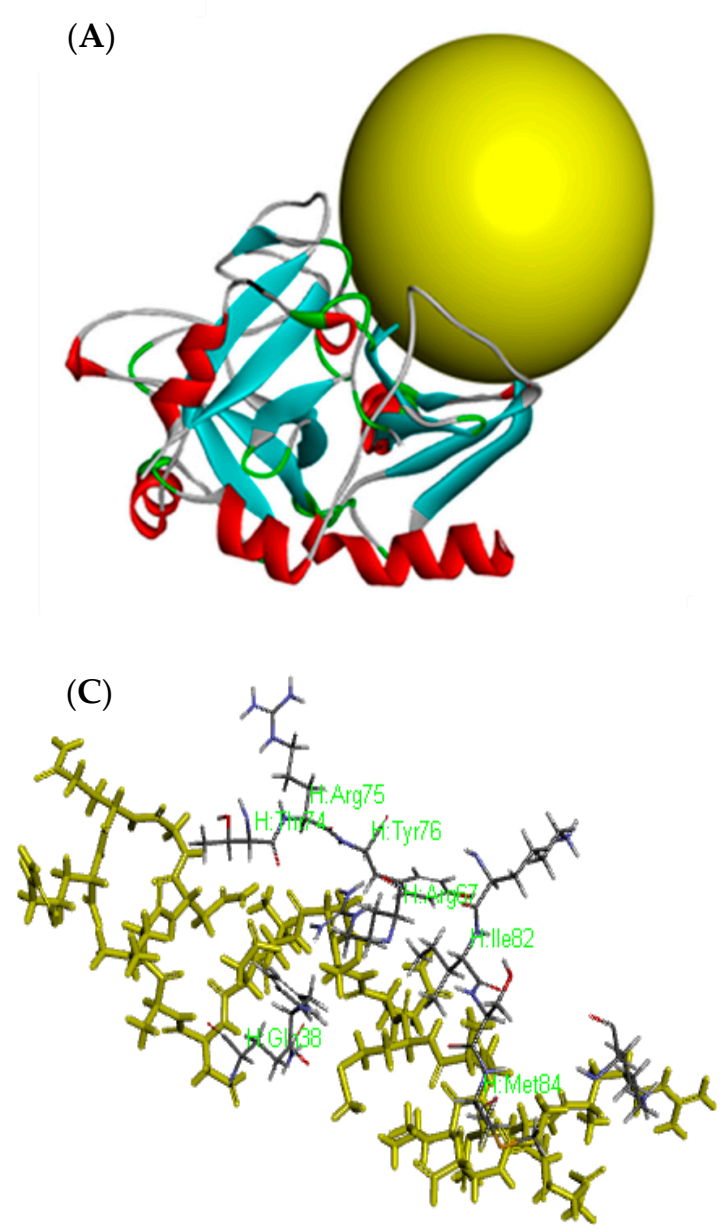

RMEADIAAMQSDLDDALNGQR

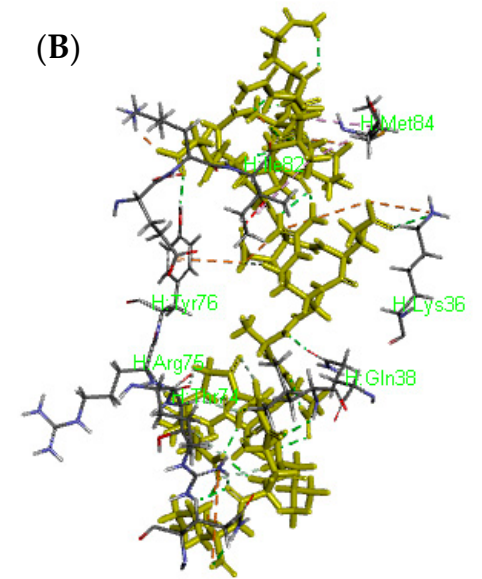

VQQELEDAEERADSAEGSLQK

(D)

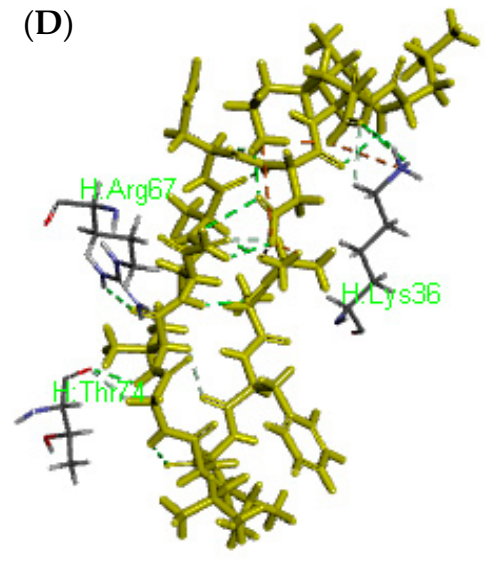

AAFLLGVNSNDLLK

(E)

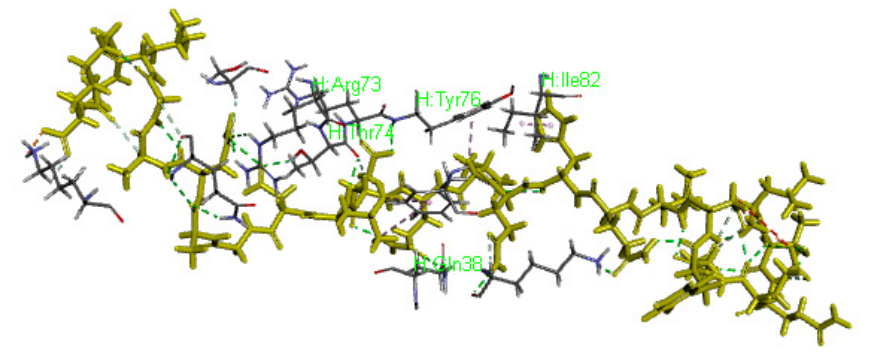

LTQENFDLQHQVQELDGANAGLAK

Figure 3. Molecular docking for the interactions of peptide against Thrombin. Molecular structure of thrombin from PDB database (A), the yellow sphere showed the docking position; VQQELEDAEERADSAEGSLQK (B), RMEADIAAMQSDLDDALNGQR (C), AAFLLGVNSNDLLK (D), and LTQENFDLQHQVQELDGANAGLAK (E). The peptides were marked with yellow sticks; the other sticks are the interactive amino acids of thrombin.

\subsection{Anticoagulant Activity Determination}

Anticoagulant activity $\mathrm{IC}_{50}$ values of hydrolysate from adductor muscle $(0.5 \sim 4 \mathrm{mg} / \mathrm{mL})$ were determined as shown in Figure 4. Results showed that $\mathrm{IC}_{50}$ was $1.49 \mathrm{mg} / \mathrm{mL}$ according to the fitted 
equation $\left(y=2.52+39.27 x-4.99 x^{2}\right)$. Moreover, the anticoagulant activity of the samples, foot, byssus, pedal retractor muscle, mantle, gill, and other parts at the same concentration were determined, and the inhibition rate was $43.14 \pm 1.29(\%), 48.50 \pm 0.5(\%), 27 \pm 2.6(\%), 22.55 \pm 3.7(\%), 19.71 \pm 2.8(\%)$, and $24.58 \pm 0.81(\%)$, respectively. These results indicated that the hydrolysate from the adductor muscle showed a higher anticoagulant activity than other tissues.

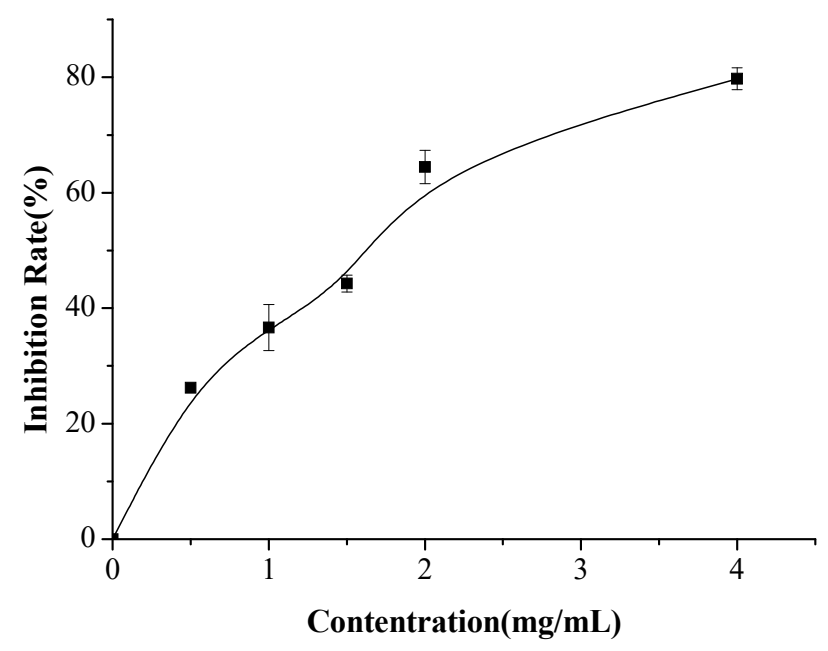

Figure 4. Anticoagulant activity IC50 of enzymatic hydrolysate from adductor muscle. Five different concentrations $(0.5 \sim 4 \mathrm{mg} / \mathrm{mL})$ were investigated, as measured by a microplate reader.

\section{Materials and Methods}

\subsection{Materials and Chemicals}

Bicinchonininc acid (BCA) and Cleanert S C18-N solid phase extraction (SPE) column were purchased from Beyotime (Beijing Baoxidi Science \& Technology Co., Ltd., Beijing, China); Thrombin (EC 3.4.21.5), formic acid (FA), and acetonitrile (ACN) were purchased from Sigma-Aldrich Co. (St. Louis, MO, USA); Trypsin (EC3.4.21.4, $2.5 \times 10^{5} \mathrm{U} / \mathrm{g}$ ) was purchased from Solarbio (Beijing, China). All other chemicals used in this study were of analytical grade.

\subsection{Split of Mytilus edulis Organisms}

M. edulis was manually split into eight parts, i.e., the foot, byssus, pedal retractor muscle, mantle, gill, adductor muscle, viscera, and other parts; these were numbered S1, S2, S3, S4, S5, S6, S7, and S8, respectively, and the Whole $M$. edulis was named S0. The samples were freeze-dried with a vacuum freeze dryer (Ningbo Scientz Biotechnology Co. Ltd., Ningbo, China). The consequent powders were also treated with a ball-milled machine (RETSCH Verder Shanghai Instruments and Equipment Co., Ltd., Shanghai, China), and stored in a dry dish at $4{ }^{\circ} \mathrm{C}$.

\subsection{SDS-PAGE}

The protein content of the samples was determined by the Kjeldahl method $[24,25]$. SDS-PAGE was carried out using AE-8135 (ATTO CORPORATION, Taito-ku, Japan). SDS-PAGE was performed using $10 \%$ polyacrylamide resolved gel $(\mathrm{pH}=8.8)$ and $5 \%$ stacking gel $(\mathrm{pH}=6.8)$. The protein bands were stained with Coomassie brilliant blue R-250. Premixed Protein Standard (44.3-200 kDa) of Takara Co. Ltd. (Dalian, China) was used for finding the relative molecular weight. The samples were mixed with $10 \mu \mathrm{L}$ of electrophoretic loading buffer and heated for $5 \mathrm{~min}$ in a boiling water bath [26,27]. Different samples were separated by centrifugation at $8000 \mathrm{rpm}$ for $15 \mathrm{~min}$. 


\subsection{Enzymatic Hydrolysis by Trypsin}

The enzymatic hydrolysis was conducted at $45{ }^{\circ} \mathrm{C}$ and $\mathrm{pH}$ 8.5. The $\mathrm{pH}$ was kept constant at 8.5 using $0.1 \mathrm{M} \mathrm{NaOH}$ as a regulator [1]. Once the optimum $\mathrm{pH}$ and temperature conditions were achieved, the enzyme trypsin (activity $\geq 5 \mathrm{U} / \mathrm{mg}$ ) was added [28,29]. After $3 \mathrm{~h}$, trypsin was heated-deactivated at $100{ }^{\circ} \mathrm{C}$ for $10 \mathrm{~min}$ in a water bath. The leaching effect of the protein from $\mathrm{S} 0$ to S8 is demonstrated by SDS-PAGE. The protein concentration was determined by BCA method [30].

\subsection{Peptide Identification by UPLC-Q-TOF-MS/MS}

The samples were processed with Cleanert S C18-N Solid phase extraction column [31]. Freeze-dried peptides were dissolved in $0.1 \%$ FA (soluble in water) and filtered through a $0.22-\mu \mathrm{M}$ microporous filter membrane (Millipore, Billerica, MA, USA) before detection by mass spectrometry. Chromatographic separation was carried out at a flow rate of $0.4 \mathrm{~mL} / \mathrm{min}$ with an injection volume of $15 \mu \mathrm{L}$ on a C18 column $(150 \times 3 \mathrm{~mm}, 3 \mu \mathrm{m}$ particle size). Peptides were separated using $0.1 \% \mathrm{FA}$ in ultrapure water (solvent A) and $0.1 \%$ FA in ACN (solvent B) at a constant temperature of $25{ }^{\circ} \mathrm{C}$. The gradient elution program was as follows: (i) $0 \min 90 \% \mathrm{~A}$; (ii) $0-2 \min 75 \% \mathrm{~A}$; (iii) $2-10 \mathrm{~min} 50 \% \mathrm{~A}$; (iv) 10-20 $\min 40 \% \mathrm{~A}$; (v) 20-35 $\min 60 \% \mathrm{~A}$; (vi) 35-40 min 90\% A [32,33].

Peptides were analyzed using an ESI-MS/MS (Bruker Co. Ltd., Bremen, Germany) with an ion source of ESI coupled with LC system (Thermo Fisher Scientific Co. Ltd., Waltham, MA, USA). The molecular mass and amino acid sequence of the peptides were determined by Mascot searching as follows: (i) The protein database was from the National Center for Biotechnology Information (https:/ / www.ncbi.nlm.nih.gov/); (ii) the enzyme was set as trypsin; and (iii) the significance threshold was $p<0.05$. The peptides were identified by database matching as well as the manual interpretation of its MS/MS spectrum, and the ion score of 35 was regarded as the identifying threshold [34].

\subsection{Activity Prediction by Peptide Ranker}

The activity of the peptides in samples $0-8$ was predicted by the software of Peptide Ranker (http://bioware.ucd.ie/ compass/biowareweb/Serverpages/peptideranker.php). Peptide Ranker is a kind of database that provides certain classes of bioactive peptides with specific structural features that endow their particular functions by different classes of peptides. It concluded that there are general shared features of bioactive peptides across different functional classes, indicating that computational prediction may accelerate across many functional classes. The implementation of the predictive method was used to identify among a set of peptides [35]. The peptides with a score of more than 0.5 were considered to be positive results in the present study.

\subsection{Molecular Docking}

Molecular docking of the estimated anticoagulant peptides with thrombin were carried out using Discovery Studio 2017 software (Neotrident Technology Ltd., Beijing, China) according to the method described with some modifications [18]. The structure of peptide was processed and the energy minimized using the steepest descent and conjugate gradient techniques [36]. The corresponding receptor protein was downloaded from the PDB database (http: / / www.rcsb.org/pdb/home/home.do) and also treated by completing the missing amino acids, removing water molecules, and so on [37]. Docking was performed using the CDOCKER docking tool of Discovery Studio software. The best ranked docking pose of peptides in the active site of thrombin was obtained according to the score and binding-energy value [36].

\subsection{Determination of Antithrombotic Peptides}

A microplate reader was set to a wavelength of $405 \mathrm{~nm}$ at $37^{\circ} \mathrm{C}$. The fibrinogen, thrombin, and the samples were all dissolved in $0.05 \mathrm{M}$ Tris- $\mathrm{HCl}$ ( $\mathrm{pH}$ 7.2) containing $0.154 \mathrm{mM}$ sodium chloride. Then, $140 \mu \mathrm{L}$ of $0.1 \%$ fibrinogen solution and $40 \mu \mathrm{L}$ of samples with different concentrations were added into 
the plate wells, mixed, and the absorbance of the sample blank was measured. Furthermore, $10 \mu \mathrm{L}$ of thrombin $(12 \mathrm{U} / \mathrm{mL})$ were added and incubated at $37^{\circ} \mathrm{C}$. Finally, the absorbance was measured after $10 \mathrm{~min}[36,38-40]$. The control group contained $40 \mu \mathrm{L}$ of Tris- $\mathrm{HCl}$ buffer instead of the sample. The inhibition rate was calculated according to the following Equation (1), where $C, C b, S$, and $S b$ represent the absorbance of control, control blank, sample, and sample blank, respectively.

$$
\text { Inhibitory Rate }(\%)=\frac{(C-C b)-(S-S b)}{C-C b} \times 100 \%
$$

\subsection{Statistical Analysis}

Values were expressed as the mean $\pm \mathrm{SD}(n \geq 3)$. Following the assessment of significant differences between samples by one-way analysis of variance (ANOVA), the level of significance was set at $p<0.05$. All statistical tests were conducted using SPSS software 19.0 (SPSS Inc., Chicago, IL, USA).

\section{Conclusions}

Different peptides components would be produced in the protein hydrolysates of the different tissues from $M$. edulis, which was digested by trypsin. Compared with the sample of blue mussels as a whole, many more peptides can be identified by UPLC-Q-TOF-MS if the tissues are identified separately. The $\mathrm{IC}_{50}$ of the hydrolysate from the adductor muscle of $M$. edulis was $1.49 \mathrm{mg} / \mathrm{mL}$. The antithrombotic activity of different hydrolysates of M. edulis proteins can probably be attributed to the bioactive peptides in them, such as VQQELEDAEERADSAEGSLQK, RMEADIAAMQSDLDDALNGQR, and AAFLLGVNSNDLLK and so on; these peptides have a relative stronger affinity with thrombin (PDB: 2BVR). The present study may provide new ideas and technology on the screening or identification of peptides with anticoagulant activity on a large scale.

Author Contributions: M.Q. conceived and designed the experiments, performed the experiments, analyzed the data, contributed reagents/materials/analysis tools, wrote the paper, prepared the figures and tables, and reviewed drafts of the paper. M.D. conceived and designed the experiments, analyzed the data, contributed reagents/materials/analysis tools, and reviewed drafts of the paper. M.T., H.C., F.M., and C.Y. have reviewed drafts of the paper.

Acknowledgments: This work was supported by the State Key Research and Development Plan Modern Food Processing and Food Storage and Transportation Technology and Equipment (2017YFD0400201), the National Natural Science Foundation of China (31771926, 31730069).

Conflicts of Interest: There is no conflict of interest.

\section{References}

1. Lafarga, T.; Aluko, R.E.; Rai, D.K.; Oconnor, P.; Hayes, M. Identification of bioactive peptides from a papain hydrolysate of bovine serum albumin and assessment of an antihypertensive effect in spontaneously hypertensive rats. Food Res. Int. 2016, 81, 91-99. [CrossRef]

2. Je, J.Y.; Park, P.J.; Byun, H.G.; Jung, W.K.; Kim, S.K. Angiotensin I converting enzyme (ACE) inhibitory peptide derived from the sauce of fermented blue mussel, Mytilus edulis. Bioresour. Technol. 2005, 96, 1624-1629. [CrossRef] [PubMed]

3. Liu, R.; Zheng, W.W.; Li, J.; Wang, L.C.; Wu, H.; Wang, X.Z.; Shi, L. Rapid identification of bioactive peptides with antioxidant activity from the enzymatic hydrolysate of Mactraveneriformis by UHPLC-Q-TOF mass spectrometry. Food Chem. 2015, 167, 484-489. [CrossRef] [PubMed]

4. Switzar, L.; Giera, M.; Niessen, W.M.A. Protein digestion: An overview of the available techniques and recent developments. J. Proteome Res. 2013, 12, 1067-1077. [CrossRef] [PubMed]

5. Kim, Y.S.; Ahn, C.B.; Je, J.Y. Anti-inflammatory action of high molecular weight Mytilus edulis hydrolysates fraction in LPS-induced RAW264.7 macrophage via NF-kB and MAPK pathways. Food Chem. 2016, 202, 9-14. [CrossRef] [PubMed] 
6. Hernroth, B.; Baden, S.; Tassidis, H.; Hornaeus, K.; Guillemant, J.; Bergstrom, L.; Bergquist, J. Impact of ocean acidification on antimicrobial activity in gills of the blue mussel (Mytilus edulis). Fish Shellfish Immunol. 2016, 55, 452-459. [CrossRef] [PubMed]

7. Gosset, C.C.; Nascimento, J.D.; Augé, M.; Bierbe, N. Evidence for adaptation from standing genetic variation on an antimicrobial peptide gene in the mussel Mytilus edulis. Mol. Ecol. 2014, 23, 3000-3012. [CrossRef] [PubMed]

8. Wang, B.; Li, L.; Chi, C.F.; Ma, J.H.; Luo, H.; Xu, Y.F. Purification and characterization of a novel antioxidant peptide derived from blue mussel (Mytilus edulis) protein hydrolysate. Food Chem. 2013, 138, 1713-1719. [CrossRef] [PubMed]

9. Park, S.Y.; Ahn, S.Y.; Je, J.Y. Antioxidant and Anti-Inflammatory Activities of Protein Hydrolysates from Mytilus edulis and Ultrafiltration Membrane Fractions. J. Food Biochem. 2014, 38, 460-468. [CrossRef]

10. Jung, W.K.; Kim, S.K. Isolation and characterization of an anticoagulant oligopeptide from blue mussel, Mytilus edulis. Food Chem. 2009, 117, 687-692. [CrossRef]

11. Goulas, S.; Gatos, D.; Barlo, K. Convergent solid-phase synthesis of hirudin. J. Pept. Sci. 2006, 12, 116-123. [CrossRef] [PubMed]

12. Davie, E.W.; Fujikawa, K.; Kisiel, W. The coagulation cascade: Initiation, maintenance, and regulation. Biochemistry 1991, 30, 10363-10370. [CrossRef] [PubMed]

13. Luchtman-Jones, L.; Broze, G.J. The current status of coagulation. Ann. Med. 1995, 27, 47-52. [CrossRef] [PubMed]

14. Salmaso, V.; Sturlese, M.; Cuzzolin, A.; Moro, S. Exploring Protein-Peptide Recognition Pathways Using a Supervised Molecular Dynamics Approach. Structure 2017, 25, 655-662. [CrossRef] [PubMed]

15. Alizadeh, A.A.; Hamzeh-Mivehroud, M.; Farajzadeh, M.; Dastmalchi, S. Identification of novel peptides against TNF- $\alpha$ using phage display technique and in silico modeling of their modes of binding. Eur. J. Pharm. Sci. 2017, 96, 490-498. [CrossRef] [PubMed]

16. Garciamora, P.; Martinmartinez, M.; Bonache, M.A.; Gonzalezmuniz, R.; Penas, E.; Frias, J.; Martinezuillaluenga, C. Identification, functional gastrointestinal stability and molecular docking studies of Lentil peptides with dual antioxidant and Angiotensin I converting enzyme inhibitory activities. Food Chem. 2017, 221, 464-472. [CrossRef] [PubMed]

17. Wu, Q.Y.; Du, J.J.; Jia, J.Q.; Kuang, C. Production of ACE inhibitory peptides from sweet sorghum grain protein using alcalase: Hydrolysis kinetic, purification and molecular docking study. Food Chem. 2016, 199, 140-149. [CrossRef] [PubMed]

18. Tu, M.L.; Feng, T.L.; Wang, Z.Y.; Qiao, M.L.; Shahidi, F.; Lu, W.H.; Du, M. Sequence analysis and molecular docking of antithrombotic peptides from casein hydrolysate by trypsin digestion. J. Funct. Foods 2017, 32, 313-323. [CrossRef]

19. Hao, S.X.; Hou, X.; Wei, L.; Li, J.; Li, Z.H.; Wang, X.T. Extraction and identification of the pigment in the adductor muscle scar of Pacific Oyster Crassostrea gigas. PLoS ONE 2015, 10. [CrossRef] [PubMed]

20. Chen, Y.; Wu, S.; Pan, S. Effect of water-soluble chitosan in combination with glutathione on the quality of pen shell adductor muscles. Int. J. Biol. Macromol. 2015, 72, 1250-1253. [CrossRef] [PubMed]

21. Neumann, T.; Junker, H.D.; Keil, O.; Burkert, K.; Ottleben, H.; Gamer, J.; Sekul, R.; Deppr, H.A.; Feurer, D.; Tomandl, G. Discovery of thrombin inhibitor fragments from chemical microarray screening. Lett. Drug Des. Discov. 2005, 2, 590-594. [CrossRef]

22. Bode, W. Structure and interaction modes of thrombin. Blood Cells Mol. Dis. 2006, 36, 122-130. [CrossRef] [PubMed]

23. Biela, A.; Khayat, M.; Tan, H.; Kong, J.; Heine, A.; Hangauer, D.; Klebe, G. Impact of ligand and protein desolvation on ligand binding to the S1 pocket of thrombin. J. Mol. Biol. 2012, 418, 350-366. [CrossRef] [PubMed]

24. Kjeldahl, J. Neue method zur bestimmung des stickstoffs in organischen körpern. Fresenius J. Anal. Chem. 1883, 22, 366-382. [CrossRef]

25. Lynch, J.M.; Barbano, D.M. Kjeldahl nitrogen analysis as a reference method for protein determination in dairy products. J. AOAC Int. 1999, 82, 1389-1398. [PubMed]

26. Marbaix, H.; Budinger, D.; Dieu, M.; Fumiere, O.; Gillard, N.; Delahaut, P.; Mauro, S.; Raes, M. Identification of proteins and peptide biomarkers for detecting banned Processed Animal Proteins (PAPs) in meat and bone meal by mass spectrometry. J. Agric. Food Chem. 2016, 64, 2405-2414. [CrossRef] [PubMed] 
27. Ketnawa, S.; Liceaga, A.M. Effect of Microwave Treatments on Antioxidant Activity and Antigenicity of Fish Frame Protein Hydrolysates. Food Bioprocess Technol. 2017, 10, 582-591. [CrossRef]

28. Hörnaeus, K.; Guillemant, J.; Mi, J.; Hernroth, B.; Bergquit, J.; Lind, B.S. Mass spectrometry data from a quantitative analysis of protein expression in gills of immuno-challenged blue mussels (Mytilus edulis). Data Brief 2016, 8, 470-473. [CrossRef] [PubMed]

29. Khaket, T.P.; Singh, J. Potential of plant's dipeptidyl peptidase I \& II homologs in generation of ace inhibitory peptides. Int. J. Pept. Res. Ther. 2017, 23, 81-90.

30. Krieg, R.C.; Dong, Y.; Schwamborn, Y.; Knueche, R. Protein quantification and its tolerance for different interfering reagents using the BCA-method with regard to 2D SDS-PAGE. J. Biochem. Biophys. Methods 2005, 65, 13-19. [CrossRef] [PubMed]

31. Iqbal, J.; Li, W.; Ullah, K.; Hasan, M.; Linna, G.; Awan, U.; Zhang, Y.Q.; Batool, S.; Deng, H.L. Study of rat hypothalamic proteome by HPLC/ESI ion trap and HPLC/ESI-Q-TOF MS. Proteomics 2013, 13, 2455-2468. [CrossRef] [PubMed]

32. Feng, L.T.; Tu, M.L.; Qiao, M.L.; Fan, F.J.; Chen, H.; Song, W.; Du, M. Thrombin inhibitory peptides derived from Mytilus edulis proteins: Identification, molecular docking and in silico prediction of toxicity. Eur. Food Res. Technol. 2018, 244, 207-217. [CrossRef]

33. Capriotti, A.L.; Caruso, G.; Cavaliere, C.; Samperi, R.; Ventura, S.; Chiozzi, R.Z.; Laganà, A. Identification of potential bioactive peptides generated by simulated gastrointestinal digestion of soybean seeds and soy milk proteins. J. Food Compos. Anal. 2015, 44, 205-213. [CrossRef]

34. Rawendra, R.D.S.; Chang, C.I.; Chen, H.H.; Huang, T.; Hsu, J. A novel angiotensin converting enzyme inhibitory peptide derived from proteolytic digest of Chinese soft-shelled turtle egg white proteins. J. Proteom 2013, 94, 359-369. [CrossRef] [PubMed]

35. Mooney, C.; Haslam, N.J.; Pollastri, G.; Shields, D.S. Towards the improved discovery and design of functional peptides: Common features of diverse classes permit generalized prediction of bioactivity. PLOS ONE 2012, 7. [CrossRef] [PubMed]

36. Wu, Q.Y.; Jia, J.Q.; Yan, H.; Du, J.J.; Gui, Z.Z. A novel angiotensin-I converting enzyme (ACE) inhibitory peptide from gastrointestinal protease hydrolysate of silkworm pupa (Bombyx mori) protein: Biochemical characterization and molecular docking study. Peptides 2015, 68, 17-24. [CrossRef] [PubMed]

37. Lin, K.; Zhang, L.W.; Han, X.; Cheng, D.Y. Novel angiotensin I-converting enzyme inhibitory peptides from protease hydrolysates of Qula casein: Quantitative structure-activity relationship modeling and molecular docking study. J. Funct. Foods 2017, 32, 266-277. [CrossRef]

38. Yang, W.G.; Wang, Z.; Xu, S.Y. A new method for determination of antithrombotic activity of egg white protein hydrolysate by microplatereader. Chin. Chem. Lett. 2007, 18, 449-451. [CrossRef]

39. Zhang, S.B.; Wang, Z.; Xu, S.Y. Antioxidant and antithrombotic activities of rapeseed peptides. J. Am. Oil Chem. Soc. 2008, 85, 521-527. [CrossRef]

40. Charles, R.S.T.; Padmanabhan, K.; Arni, R.V.; Padmanabhan, K.P.; Tulinsky, A. Structure of tick anticoagulant peptide at 1.6 Å resolution complexed with bovine pancreatic trypsin inhibitor. Protein Sci. 2000, 9, 265-272. [CrossRef] [PubMed]

(C) 2018 by the authors. Licensee MDPI, Basel, Switzerland. This article is an open access article distributed under the terms and conditions of the Creative Commons Attribution (CC BY) license (http://creativecommons.org/licenses/by/4.0/). 